HEALTH AND SAFETY RESEARCH DIVISION

Waste Management Research and Development Programs (Activity No. AH 1005000 ; NEAH317)

\title{
RESULTS OF MOBILE GAMMA SCANNING ACTIVITIES IN TONAWANDA, NEW YORK
}

\author{
W. D. Cottrell, D. A. With,
}

R. E. Rodriguez, and R. F. Carrier

Publication issued - December 1990

\begin{abstract}
Investigation Team
R. E. Swaja - Measuremeni Applications and Development Manager

W. D. Cottrell - FUSRAP Project Director
\end{abstract}

Survey Team Members

W. D. Cottrell R. E. Rodriguez

V. P. Patania

G. K. Stowe*

I. A. Witt

*Oak Ridge / sssociated Universities

\section{Work performed by the \\ MEASUREMENT APPLICATIONS AND DEVELOPMENT GROUP}

Prepared by the

OAK RIDGE NATIONIL LABORATORY

Oak Ridge, Tennessee 37831-6285

managed by

MARTIN MARIETTA ENERGY SYSTEMS, INC.

for the

U. S. DEPARTMENT OF ENERGY

under contract DE-AC05-84OR21400

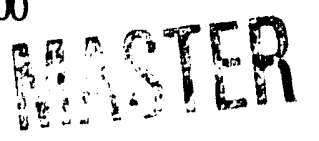




\section{CONTENTS}

LIST OF FIGURES $\ldots \ldots \ldots \ldots \ldots \ldots \ldots \ldots \ldots \ldots \ldots \ldots \ldots \ldots \ldots \ldots$

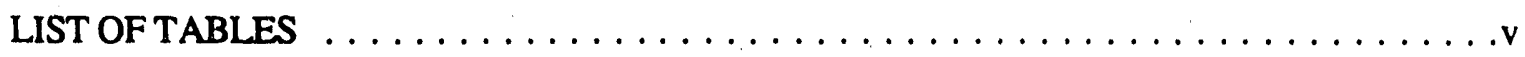

ACKNOWLEDGMENTS $\ldots \ldots \ldots \ldots \ldots \ldots \ldots \ldots \ldots \ldots \ldots \ldots \ldots \ldots$ vii

ABSTRACT. . . . . . . . . . . . . . .

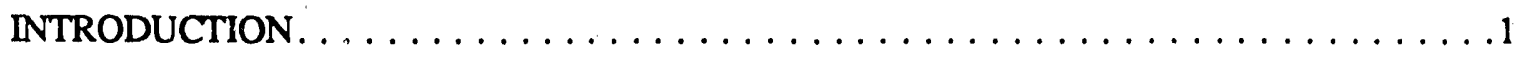

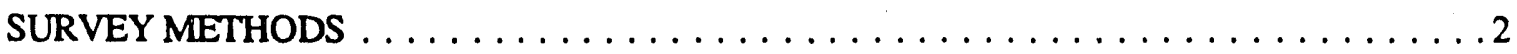

MOBILE SCANNING METHOD $\ldots \ldots \ldots \ldots \ldots \ldots \ldots \ldots \ldots \ldots \ldots$

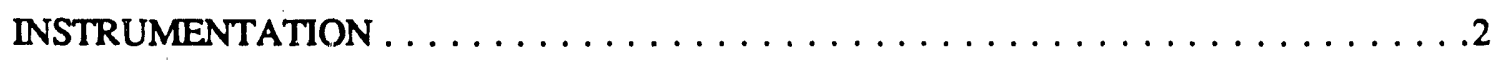

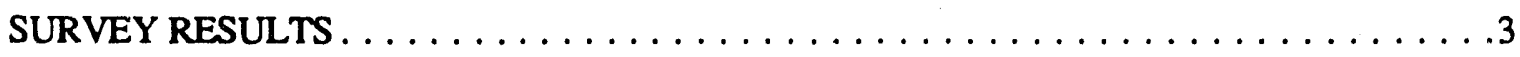

SIGNIFICANCE OF FINDINGS $\ldots \ldots \ldots \ldots \ldots \ldots \ldots \ldots \ldots \ldots \ldots \ldots$

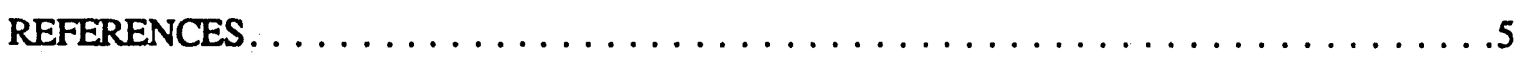




\section{LIST OF FIGURES}

1 Diagram showing relative locations of the sites in Tonawanda,

New York, surveyed with the mobile scanning vehicle $\ldots \ldots \ldots \ldots \ldots$

2 Diagram of route scanned near the Linde Plant site and locations of biased soil samples collected from anomalous areas $\ldots \ldots \ldots \ldots \ldots \ldots$

3 Diagram of route scanned near the Tonawanda landfill showing location of biased soil sample collected from an anomalous area $\ldots \ldots \ldots \ldots \ldots \ldots \ldots$

4 Diagram of route scanned near the Waste Water Treatment Plant, Tonawanda, New York . . . . . . . . . . . . . . . . . . . . . . . .9

5 Diagram of route scanned near the Sheridan Park Fire District 4

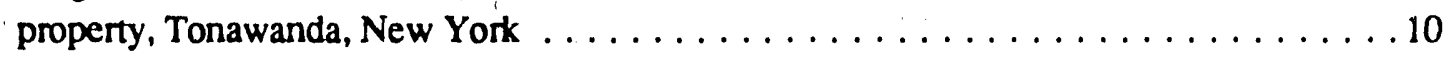

\section{LIST OF TABLES}

1 Radionuclide concentrations in soil samples from areas near the Linde Plant property, Tonawanda, New York . . . . . . . . . . . . . 11 


\section{ACKNOWLEDGMENTS}

Research for this project was sponsored by the U. S. Department of Energy's Office of Environmental Restoration, under contract DE-AC05-84OR21400 with Martin Marietta Energy Systems, Inc. The authors gratefully acknowledge the assistance of the following members of Oak Ridge National Laboratory (ORNL): M. S. Blair of the Instrumentation and Controls Division; V. P. Patania, D. A. Roberts, D. A. Rose, and T. A. Stewart of the Measurement Applications and Development Group; and G. Stowe of the Pollutant Assessments Group. The contributions of these individuals to the collection, analysis, and recording of data for this survey and to the preparation of graphics made this report possible. 


\begin{abstract}
During the 1940s, the Linde Air Products Division of Union Carbide operated a plant in Tonawanda, New York, for the Manhattan Engineer District (MED) and the Atomic Energy Commission (AEC). Uranium production and some nickel processing wer 2 conducted at the site. It is the policy of the U. S. Department of Energy (DOE) to verify that radiological conditions at such sites or facilities comply with current DOE guidelines. Guidelines for release and use of such sites have become more stringent as research has provided more information since previous cleanups. The Formerly Utilized Sites Remedial Action Program (FUSRAP) was established as part of that effort to confirm the closeout status of facilities under contract to agencies preceding DOE during early nuclear energy development.

Under the FUSRAP program, the Linde site itself has been previously investigated to determine the extent of on-site radiological contamination. As a precaution to insure that no residual radioactive materials were transported off-site, the Department of Energy (DOE) requested that ORNL survey the area in the vicinity of the Linde Plant, the waste water treatment facility on Tower Road, the Sheridan Park Fire Station (District 4), and the Tonawanda Landfill to assess whether any residual radioactive material could be detected. The survey was conducted the week of April 3, 1990.

Results of analysis of soil samples from the Tonawanda Landfill revealed slightly elevated concentrations of $238 \mathrm{U}$ and $226 \mathrm{Ra}$ suggestive of residuals from former Linde Plant operations. Therefore, it is recommended that additional surveying of the landfill property and of Sheridan Creek from south of the Linde property to its confluence with the Niagara River be conducted. The survey should include the measurement of gamma radiation levels and radionuclide analysis of silt samples.
\end{abstract}




\section{RESULTS OF MOBILE GAMMA SCANNING ACTIVITIES IN TONAWANDA, NEW YORK*}

\section{INTRODUCTION}

From 1942 through approximately 1948, the Linde Air Products Division of Union Carbide operated a plant in Tonawanda, New York, for the Manhattan Engineer District (MED) and the Atomic Energy Commission (AEC). Uranium production and some nickel processing were conducted at the site, known as the Ceramics Plant, under several contracts. Operations included the conversion of black oxide $\left(\mathrm{U}_{3} \mathrm{O}_{8}\right)$ from Beigian Congo pitchblende ore and from concentrates from Colorado Plateau ore during the first three years of operation. A process for converting the uranium oxide to uranium tetrafluoride ( $\mathrm{UF}_{4}$ ) was also conducted at the site during World War II and for two subsequent years. Processing residues from the operations were stored either at what is now known as the U.S. Department of Energy (DOE) Niagara Falls Storage Site or at the nearby Haist property now owned by the Ashland Oil Company. Some liquid wastes from the refinery operation were disposed of in sanitary sewers, storm sewers, and in shallow on-site wells.

It is the policy of the DOE to verify that radiological conditions at such sites or facilities comply with current DOE guidelines. ${ }^{1}$ If they are found to significantly exceed those guidelines, remedial action may be implemented (where DOE has the authority to do so) to correct the unacceptable condition. DOE established the Formerly Utilized Sites Remedial Action Program (FUSRAP) as part of that effort to confirm the closeout status of facilities under contract to agencies preceding DOE during early nuclear energy development. Furthermore, guidelines for release and use of such sites have become more stringent as research has provided more information since previous cleanups.

The Linde Plant property where the ceramics plant was located is bordered on the north and east by other indistries; on the south by small businesses, industries, and undeveloped land; and on the west by a golf course. The Linde site itself has been previously investigated to determine the extent of on-site radiological contamination. 2 As a follow-up to earlier investigations and as a precaution to insure that no residual radioactive materials exceeding current DOE guidelines were transported off-site, DOE requested that ORNL survey the vicinity of the Linde site to assess whether any residual radioactive material could be detected. Surveyed areas included suspected haul routes to a near-by landfill, the landfill itself, and two other sites. The latter were the waste water treatment facility on Tower Road and the Sheridan Park Fire Station (District 4) where material dredged from Sheridan Creek in front of the facility may have been dumped (Fig. 1). The survey was conducted the week of April 3,1990.

"The survey was performed by members of the Measurement Applications and Development Group of the Health and Safety Research Division of Oak Ridge National Laboratory under DOE contract DE-AC05-84OR21400. 


\section{SURYEY METHODS}

A brief description of the methods used for the mobile scanning of the described areas follows. Standard operating procedures for the mobile gamma scanning van were used to conduct the survey. ${ }^{3}$ A more detailed description of the system and operation is provided in Myrick et al. ${ }^{4}$ In areas inaccessible to the van, notably the Tonawanda Landfill, it was necessary to conduct a limited walking inspection using a hand-held portable gamma scintillometer. The scoping approach used in this scanning method is described in Procedures Manual for the ORNL Radiological Survey Activities (RASA) Program. Oak Ridge National Laboratory, ORNL/TM-8600 (April 1987). ${ }^{5}$

\section{MOBILE SCANNING METHOD}

The initial step in searching for gamma radiation anomalies with the scanning van is to obtain the baseline (background) data with which to compare measurements taken in the relevant areas. Background exposure rates were measured along thoroughfares in similar, but radiologically unenhanced regions in the vicinity of the areas of interest. Scans were then performed of the suspect areas at a slow speed ( $<5 \mathrm{mph}$ ), minimizing the distance between the detectors and the properties. All accessible areas were scanned in both directions to maximize the number of views obtained for each surveyed property. Anomaly locations were highlighted by the computer system when the preset "hit" criteria, described as follows, were exceeded during the scan.

All anomalies were verified by gamma-scanning the area with portable, hand-held gamma scintiliators. The soil in any area having elevated gamma radiation levels was then sampled and the samples analyzed for radionuclide content.

\section{INSTRUMENTATION}

The gamma radiation detection system employed in the ORNL scanning van is operator-controlled through keyboard instructions to an on-board computer on which data output is displayed. The data can be simultaneously printed and is stored on a dual floppy disk drive. The system consists of three $4 \times 4 \times 16$-in. $\mathrm{NaI}(\mathrm{TI}) \log$ crystals housed in a lead-shielded steel frame to provide a $12 \times 16$-in. detector surface area for acceptance of gamma radiation through one side of the survey van. The detector and shield height can be varied with a hydraulic lift mechanism to optimize the detector field-of-view. The detector output is transferred to a computer-controlled eight-channel discriminator and interface that provides for continuous analysis of data inputs for correlation of system location with count rate information. Separate energy regions-of-interest are anal yzed and a radionuclide-specific algorithm is employed to identify locations containing residual radium materials. Multichannel analysis capabilities are included in the system for additional qualitative radionuclide identification.

The algorithm used for data analysis compares the observed count rates arising from certain naturally occurring radionuclides to those produced by residual radioactive materials. Three regions of interest for $226 \mathrm{Ra}(609 \mathrm{keV}, 1120 \mathrm{keV}$, and $1764 \mathrm{keV}$ energy peaks from $214 \mathrm{Bi})$ and one for $232 \mathrm{Th}\left(2614 \mathrm{keV}\right.$ from $\left.{ }^{208} \mathrm{Tl}\right)$ are analyzed. A Ra/Th ratio is computed from the observed 
background (bkg) observations and this ratio is used for comparison with scan data obtained from the suspect areas. In identifying locations containing residual 226Ra-bearing material, the system utilizes criteria ("hit" criteria) based on the observed background $\mathrm{Ra}$ and Th count rates and the computed Ra/Th ratio. The "hit" criteria used are the following:

(1) a minimum count rate that results in a change in the background $\mathrm{Ra} / \mathrm{Th}$ ratio;

(2) an observed $\mathrm{Ra} / \mathrm{Th}$ ratio that is greater than the background $\mathrm{Ra} / \mathrm{Th}$ ratio $\left(\mathrm{Ra} / \mathrm{Th}_{\text {bkg }}+\sigma \mathrm{Ra} / \mathrm{Th}_{\text {bkg }}\right) ;$ and

(3) the positive difference between the observed Ra count and the background Ra count [i.e., the difference $=$ observed $\mathrm{Ra}-$ [observed $\mathrm{Th}\left(\mathrm{Ra} / \mathrm{Th}_{\mathrm{bkg}}+\sigma \mathrm{Ra} / \mathrm{Th}_{\mathrm{bkE}}\right.$ ' '] $]$. A hit is recorded when the first criterion and either the second or third criterion are met.

\section{SURVEY RESULTS}

The entire length of East Park Drive as shown on Fig. 1 from Woodward $A$ venue to and around the incinerator was scanned. Other routes scanned, that is, streets and roads adjacent to the Linde property, the Sheridan Park Fire Station (District 4), the waste treatment facility on Tower Drive, and the Tonawanda Landfill are depicted in Figs. 2 through 5. The analysis of the mobile scan data was based on background count rates measured in the regions of interest as previously described. Background concentrations have not been subtracted from radionuclide concentrations measured in environmental samples.

Analysis of the scan data indicated the presence of three anomalies each of which measured less than $1 \mathrm{~m}^{2}$ in size. Soil samples were collected at each of these locations as shown on Figs. 2 and 3. Samples B1 and B2 were taken from a single property, a transport trucking depot east of the Linde Plant on Military Road (Fig. 2). The third sample was collected from the landfill at the location shown on Fig. 3.

Results of radionuclide analysis of the samples are listed in Table 1. Uranium-238 and ${ }^{226} \mathrm{Ra}$ concentrations, 3.3 to $6.5 \mathrm{pCi} / \mathrm{g}$ and 3.5 to $5.7 \mathrm{pCi} / \mathrm{g}$, respectively, in samples B1AD, B1AR, and B2 are slightly elevated above typical average background concentrations found in Tonawanda ( 0.98 and $0.95 \mathrm{pCi} / \mathrm{g}$, respectively). 6 The fact that the elevated concentrations of $238 \mathrm{U}$ and $226 \mathrm{Ra}$ are in secular equilibrium in each sample (i.e., approximately equal) indicates that the enhancement is of natural origin and unrelated to former processing operations at the Linde Plant site. However, concentrations of $238 \mathrm{U}$ and $226 \mathrm{Ra}$ in samples B3A and B3B are significantly elevated but are not in secular equilibrium. Thus, these enhanced concentrations are probably related to past activities at the Linde Plant site. Results also show that concentrations of ${ }^{232} \mathrm{Th}$ are elevated in samples $\mathrm{B} 1$ and B2, ranging from 4.6 to $8.0 \mathrm{pCi} / \mathrm{g}$ compared to a typical average background concentration of $0.64 \mathrm{pCi} / \mathrm{g}$. However, it appears from historical data that no thorium was used at the Linde Plant and would not have been expected to result from any activity conducted at the site. The two samples having elevated thorium concentrations were taken from the parking area at a transport truck depot. The elevated thorium content was apparently caused by the natural composition of the parking lot gravel. 


\section{SIGNIFICANCE OF FINDINGS}

The results of these scanning activities revealed no evidence for the presence of radioactive residuals related to past AEC operations around the Linde Plant, the Waste Water Treatment plant, the Sheridan Park Fire District 4 property, or along the thoroughfares. However, the results of analysis of a soil sample from the Tonawanda Landfill show the presence of enhanced concentrations of radionuclides such as those that might be expected to result from former pracessing activities at the Linde Plant site. Because of this finding and because the landfill was only briefly scanned during this survey, it is ecommended that a more complete characterization of the Tonawanda landfill be conducted. In addition, Sheridan Creek had received drainage from plant storm sewers during the 1940-1948 contract operations; and, samples of plant outfall and down tream water from Sheridan Crek in 1976 showed concentrations of radium and uranium 3 to 5 times those of upstream samples (background). 2 Therefore, a complete survey of Sheridan Creek from south of the Linde property to its confluence with the Niagara River is also recommended. The survey should include the determination of gamma radiation levels and the collection and analysis of silt samples. 


\section{REFERENCES}

1. Guidelines for Residual Radioactive Material at Formerly Utilized Sites Remedial Action Program and Remote Surplus Facilities Management Program Sites, Rev. 2, U.S. Department of Energy, March 1987.

2. Radiological Survey of the Former Linde Uranium Refinery, Tonawanda, New York, Final Report, DOE/EV-0005-UC-7, Martin Marietta Energy Systems, Inc., Oak Ridge Natl. Lab., 1978.

3. C. A. Little et al., Radiological Survey Activities - Uranium Mill Tailings Remedial Action Project Procedures Manual, Martin Marietta Energy Systems, Inc., Oak Ridge Natl. Lab., ORNL/TM-9902, 1986.

4. T. E. Myrick, M. S. Blair, R. W. Doane, and W. A. Goldsmith, A Mobile Gamma-Ray Scanning System for Detecting Radiation Anomalies Associated with Ra-226 Bearing Materials, Martin Marietta Energy Systems, Inc., Oak Ridge Natl. Lab., November 19:32.

5. T. E. Myrick, B. A. Berven, W. D. Cottrell, W. A. Goldsmith, and F. F. Haywood, Procedures Manual for the ORNL Radiological Survey Activities (RASA) Program, ORNL/TM-8600, Martin Marietta Energy Systems, Inc., Oak Ridge Natl. Lab., April 1987.

6. T. E. Myrick, B. A. Bcrven, and F. F. Haywood, State Background Radiation Levels: Results of Measurements Taken during 1975-1979, ORNL/TM-7543, Martin Marietta Energy Systems, Inc., Oak Ridge Natl. Lab., November 1981. 


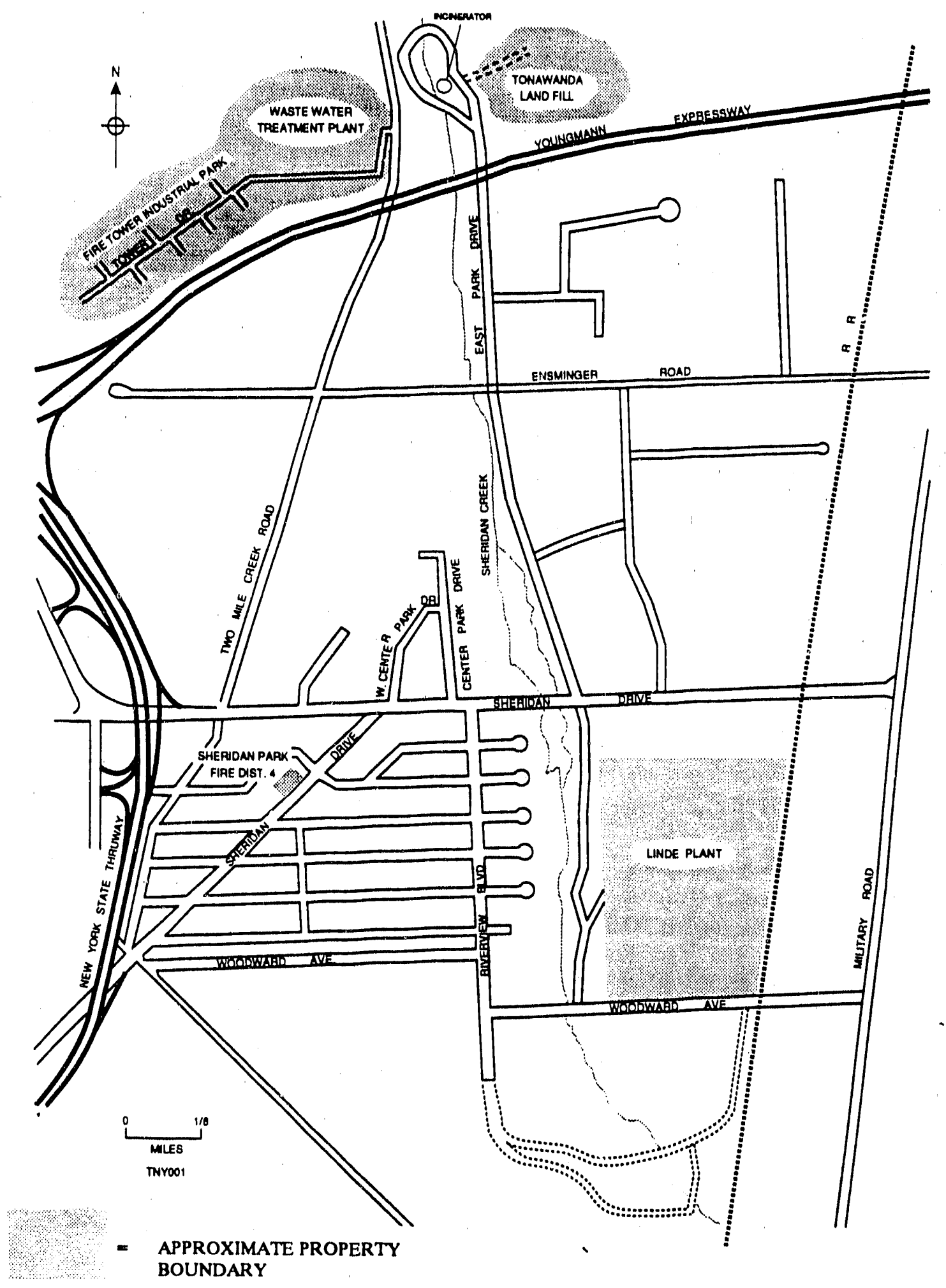

Fig. 1. Diagram showing relative locations of the sites in Tonawanda, New York, surveyed with the mobile scanning vehicle. 


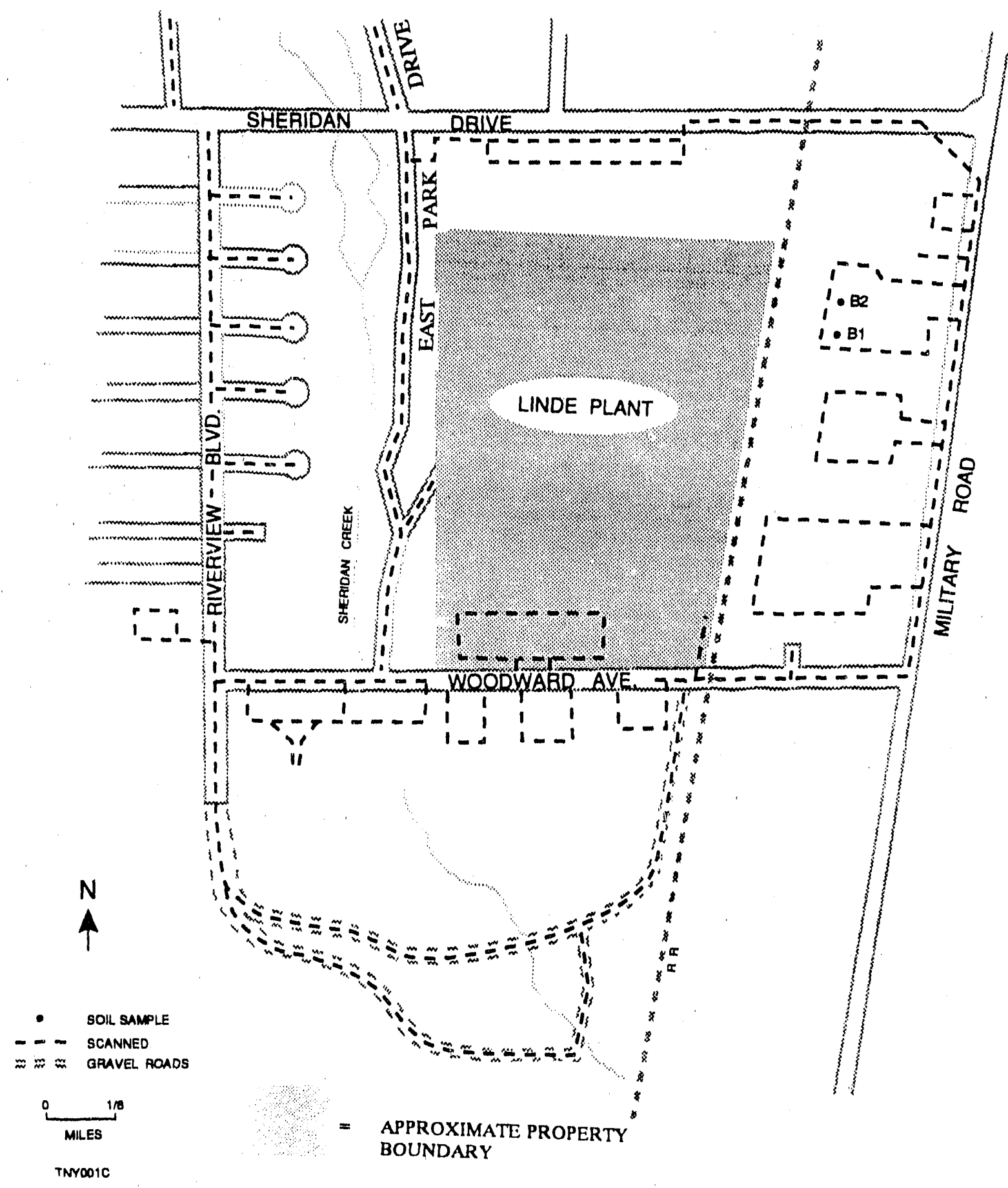

Fig. 2. Diagram of route scanned near the Linde Plant site and locations of biased soil samples collected from anomalous areas. 


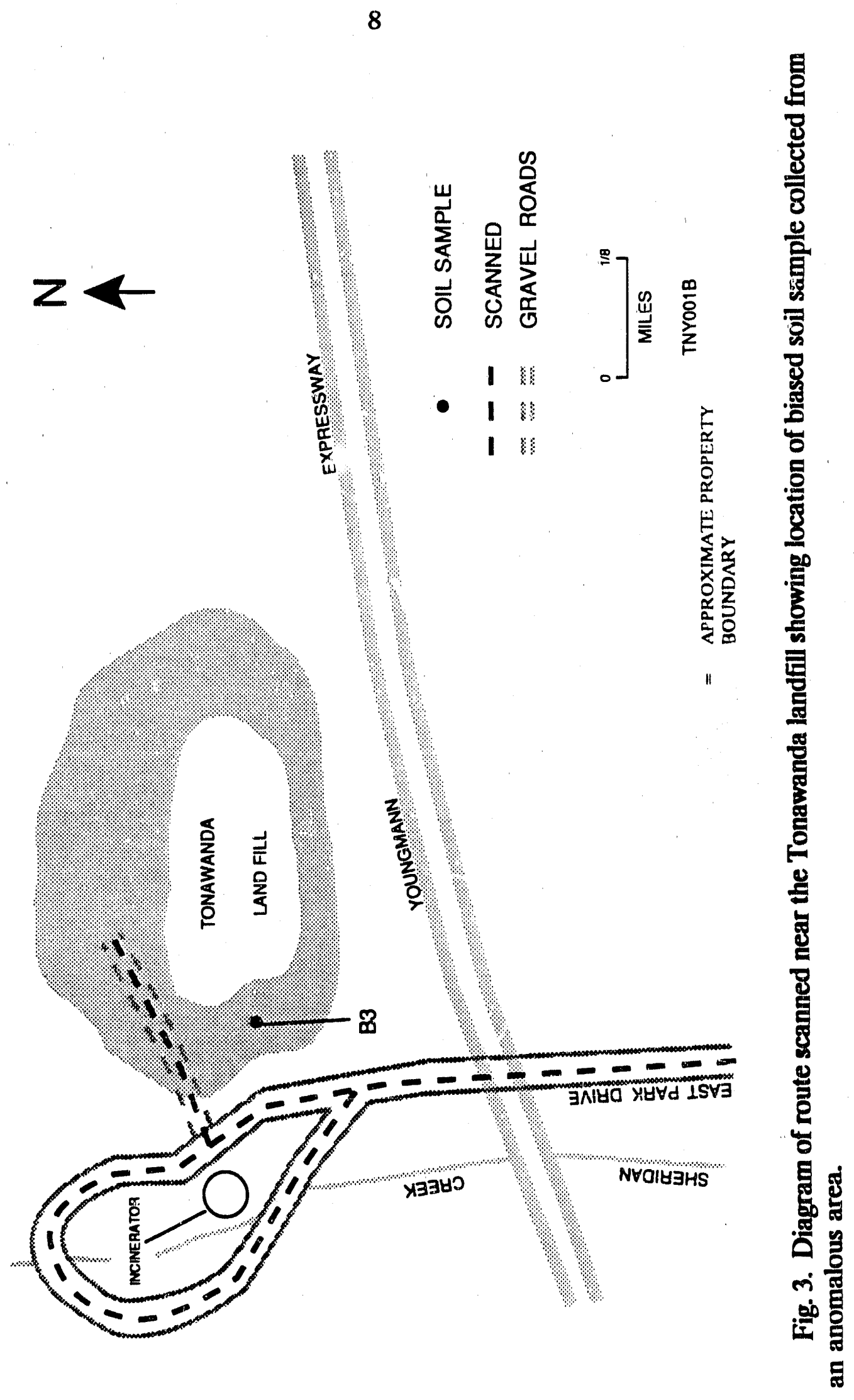




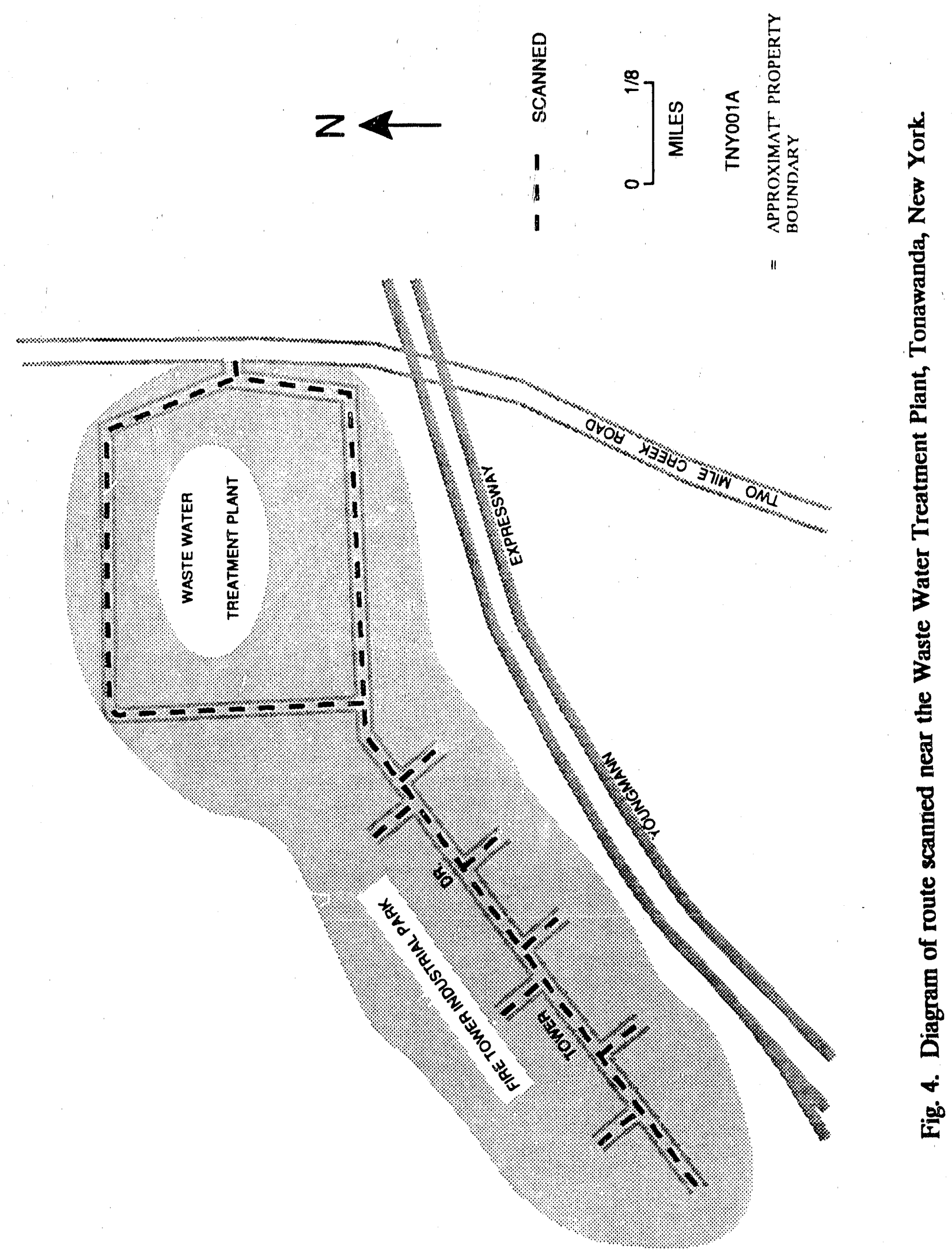




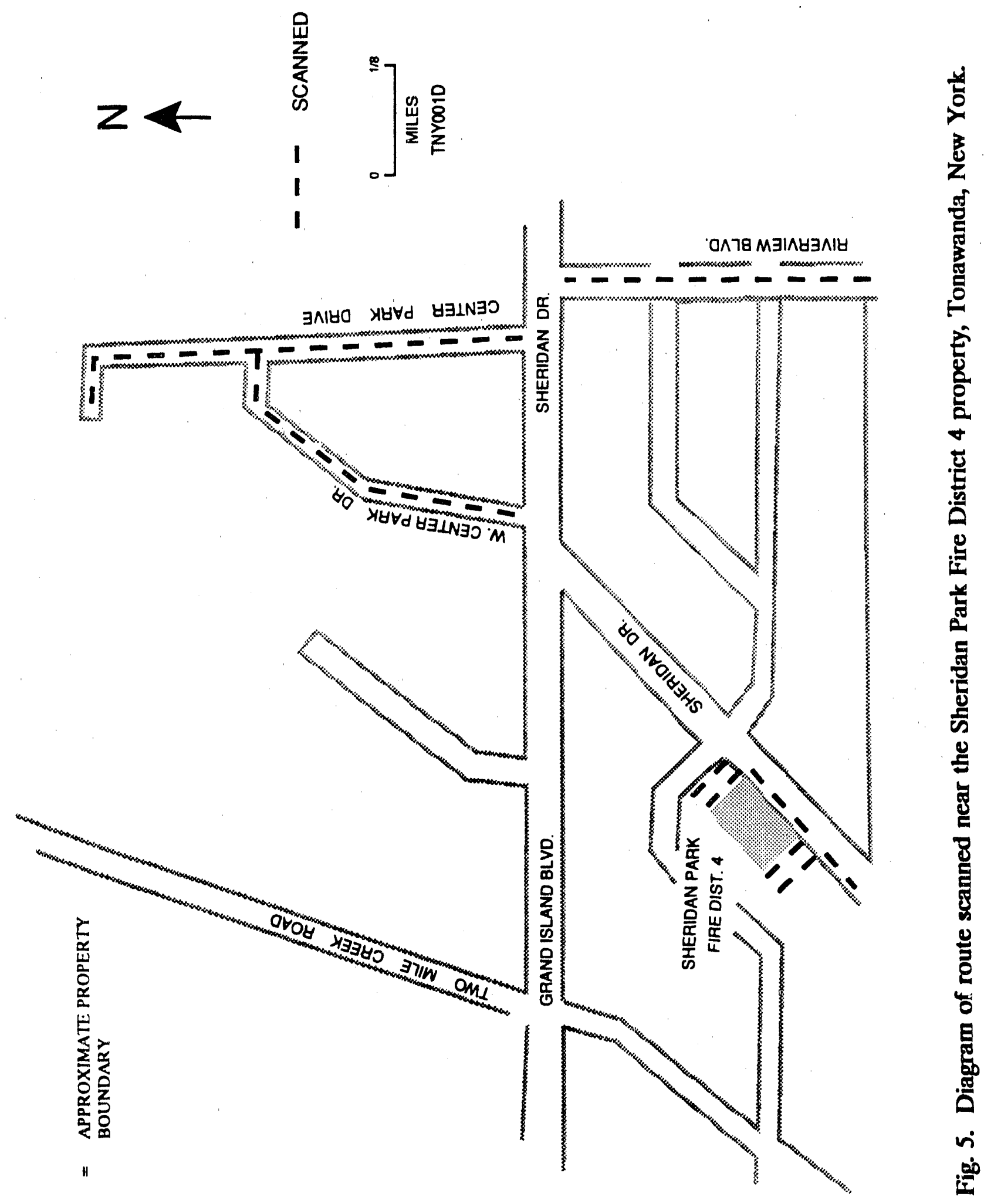


Table 1. Radionuclide concentrations in soil samples from areas near the Linde Plant property, Tonawanda, New York

\begin{tabular}{lccccccc}
\hline \multirow{2}{*}{$\begin{array}{c}\text { Sample } \\
\text { I.D. }\end{array}$} & $\begin{array}{c}\text { Depth } \\
(\mathrm{cm})\end{array}$ & \multicolumn{5}{c}{ Radionuclide concentration $(\mathrm{pCi} / \mathrm{g})^{b}$} \\
\cline { 3 - 8 } & ${ }^{238} \mathrm{U}$ & ${ }^{226} \mathrm{Ra}$ & ${ }^{232} \mathrm{Th}$ & ${ }^{137} \mathrm{Cs}$ & ${ }^{40} \mathrm{~K}$ \\
\hline $\mathrm{B} 1 \mathrm{AD}^{c}$ & $0-15$ & $3.3 \pm 1.3$ & $3.5 \pm 0.03$ & $4.6 \pm 0.05$ & $0.01 \pm 0.01$ & $8.1 \pm 0.26$ \\
B1AR $^{c}$ & $0-15$ & $6.5 \pm 0.89$ & $5.7 \pm 0.04$ & $6.6 \pm 0.16$ & $0.18 \pm 0.02$ & $3.8 \pm 0.19$ \\
$\mathrm{~B} 2$ & $0-15$ & $6.3 \pm 1.5$ & $5.3 \pm 0.04$ & $8.0 \pm 0.10$ & $0.13 \pm 0.02$ & $4.0 \pm 0.28$ \\
$\mathrm{~B} 3 \mathrm{~A}$ & $0-15$ & $18 \pm 3.0$ & $11 \pm 0.10$ & $0.84 \pm 0.07$ & $0.11 \pm 0.02$ & 16 & \pm 0.77 \\
$\mathrm{~B} 3 \mathrm{~B}$ & $15-30$ & $16 \pm 1.1$ & $5.4 \pm 0.06$ & $0.98 \pm 0.07$ & $0.03 \pm 0.02$ & 17 & \pm 0.56 \\
\hline
\end{tabular}

${ }^{a}$ Locations shown on Figs. 2 and 3.

${ }^{b}$ Indicated counting error is at $t$. c $95 \%$ confidence level $( \pm 2 \sigma)$.

${ }^{c}$ Sample $B 1$ was split into soil (D) and rock (R) fractions that were analyzed separately. 

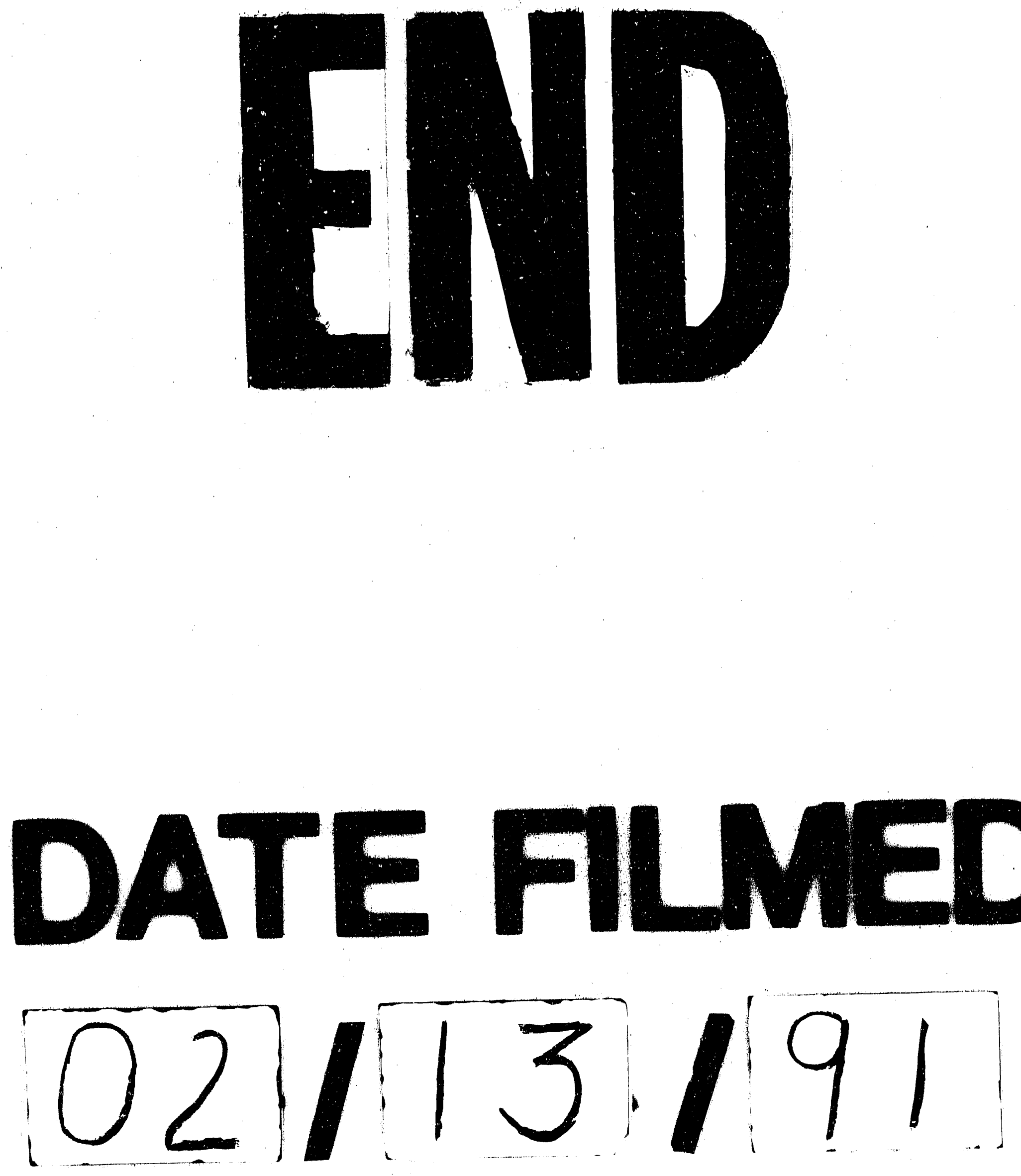
